\section{Substrate pH Impacts Efficacy of Ethephon Drenches on Growth of Herbaceous Perennials}

\author{
Margaret G. Aiken, Holly L. Scoggins, and Joyce G. Latimer ${ }^{\mathbf{1}}$ \\ Department of Horticulture, Virginia Tech, Saunders Hall, Blacksburg, VA \\ 24061
}

Additional index words. plant growth regulators, Verbena bonariensis, Veronica spicata

Abstract. Ethephon [(2-chloroethyl) phosphonic acid] is widely used as a growth regulator in floricultural crop production, with foliar sprays as the typical application method. Ethephon efficacy is determined by rate of uptake and subsequent ethylene evolution, which can be influenced by a number of factors, including solution $\mathrm{pH}$. This study examines whether an ethephon substrate drench $\left(100 \mathrm{mg} \cdot \mathrm{L}^{-1}\right.$ at a volume of $296 \mathrm{~mL}$ per 2.8-L container) would allow for plant uptake in two herbaceous perennials, Verbena bonariensis (L.) 'Lollipop' and Veronica spicata (L.) 'Goodness Grows', as measured by subsequent effects on shoot growth and days to flower. We also investigated substrate pH effects on ethephon drench efficacy by analyzing the shoot responses to ethephon applied at a range of starting substrate $\mathrm{pH}(4.5$ to 7.0$)$ compared with untreated plants grown under the same substrate pH conditions (controls). One or more measurements of shoot growth (height, width, shoot dry weight) were reduced in both taxa treated with ethephon as compared with controls. Veronica plant growth was not influenced by substrate $\mathrm{pH}$ in either the control or ethephon-drenched plants. For Verbena plants receiving the ethephon drench, as substrate $\mathrm{pH}$ increased, height and width increased. For example, when ethephon was applied at substrate $\mathrm{pH} 4.5$, finished plant height averaged $32.0 \mathrm{~cm}$, compared with $43.5 \mathrm{~cm}$ for those plants that received the drench at a substrate $\mathrm{pH}$ of 7.0. Increasing substrate pH conditions also influenced the days to flower in Verbena plants. Ethephon-treated plants at a substrate $\mathrm{pH}$ of 4.5 required an average of 6.5 days longer to flower than those at a substrate $\mathrm{pH}$ of 7.0. In summary, ethephon drench applications can result in significant growth regulation effects, as seen in both Veronica and Verbena. Furthermore, increasing substrate $\mathrm{pH}$ can reduce the efficacy of ethephon drench applications.

Ethephon [(2-chloroethyl) phosphonic acid] has been widely used as a foliar spray in the commercial greenhouse industry for decades to abort flowers, promote branching, and restrict plant growth (Kays and Beaudry, 1987). Growers have reported success with ethephon as a growth regulator (Styer, 2002), resulting in continued research on the product and specific recommendations for ethephon use. For maximum efficacy, growers are advised to spray ethephon to runoff and to ensure the leaves remain wet for 3 to $4 \mathrm{~h}$ (Styer, 2002). In addition, temperature must be considered when the spray applications are to be made. At low temperatures, the rate of ethylene generation is very slow, limiting the amount of uptake and reducing the efficacy of the chemical (Lougheed and Franklin, 1972). At temperatures above $33{ }^{\circ} \mathrm{C}$, exogenous ethephon breaks down at a high rate, which limits the amount of ethephon available for plant uptake and can potentially

Received for publication 23 Mar. 2015. Accepted for publication 10 June 2015 .

Mention of a trademark, proprietary product, or vendor does not constitute a guarantee or warranty of the product by Virginia Tech and does not imply its approval to the exclusion of other products or vendors that also may be suitable.

${ }^{1}$ Corresponding author. E-mail: jlatime@vt.edu. cause phytotoxicity in the form of leaf senescence because of the rapid increase of ethylene in the air surrounding the plant (Lougheed and Franklin, 1972; Olien and Bukovac, 1978).

Another factor influencing efficacy is $\mathrm{pH}$. Maintaining a solution $\mathrm{pH}$ between 4.0 and 4.5 when applying an ethephon spray to plants is critical. As solution $\mathrm{pH}$ increases, the rate at which ethephon evolves to ethylene also increases (Warner and Leopold, 1969). Consequently, as the speed at which ethephon evolution increases while in solution, ethephon availability for plant uptake decreases, therein reducing the chemical efficacy (Smith, 2010). Ethephon is a relatively strong acid, which will reduce the solution $\mathrm{pH}$; however, in regions with water sources with high alkalinity, the buffering capacity of the bicarbonates in the water may prevent the solution $\mathrm{pH}$ from lowering to the recommended range (Camberato et al., 2014). In these circumstances, it is necessary to reduce the $\mathrm{pH}$ of the solution by adding an acidic buffer solution to the tank before adding ethephon to prevent ethephon degradation (Yates et al., 2011). There is no doubt that ethephon's dependence on environmental and physical factors such as temperature, $\mathrm{pH}$, and leaf wetness duration contribute to the challenges growers face in achieving optimum efficacy and consistency when applying ethephon as a PGR.

Conflicting research results exist as to the mechanism of ethylene evolution within the plant. According to Warner and Leopold (1969), ethephon is absorbed into the plant tissue and subsequently ethylene generation occurs intercellularly because of the higher pH within the plant cells. However, studies conducted by Mudge and Swanson (1978) suggest that the generation of ethylene from ethephon takes place largely extracellularly. Regardless of how the ethylene evolves, once within the plant tissue, the cells respond with a reduction in cell elongation and a reduction in apical dominance, which in turn, can cause an increase in branching (Burg, 1973; Haver and Schuch, 2001).

The extent to which ethephon or ethylene translocates within the plant is also largely unknown. In studies conducted by Edgerton and Hatch (1972), ethephon was applied to sweet cherry leaves and fruit but more ethephon was recovered in the fruit 48 to $72 \mathrm{~h}$ after application than what was recovered immediately after the ethephon application, which led the authors to conclude that the majority of ethephon recovered in the fruit had translocated from the leaves. This suggests that ethephon may not need to be applied to target tissue to elicit a growth response. However, it is unknown if, and to what extent, ethephon can translocate from the roots to the shoots when applied to the substrate as a drench (Miller et al., 2012).

Currently, ethephon is not EPA labeled for commercial floriculture use as a drench application. In fact, it was widely believed in commercial horticulture that ethephon had no root activity and could only be absorbed through the leaf and stem tissue (Styer, 2002; Whipker et al., 2003). However, conflicting research results indicates that this theory is incorrect. Johnson et al. (1982) reported that ethephon drench applications reduced the intercellular spaces in Ficusbenjamina L., resulting in reduced leaf area. More recently, ethephon substrate drenches reduced stem elongation of Narcissus pseudonarcissus $\mathrm{L}$. and reduced plant growth and delayed flowering in a wide variety of bedding plants (Miller et al., 2012). Miller et al. (2012) also found that substrate $\mathrm{pH}$ affected the rate and duration of ethylene evolution from drench applications of ethephon in a closed system, in the absence of plants.

Drench applications of PGRs have many benefits to growers including a more uniform growth regulation effect across crops. In addition, generally less total chemical is used as the concentrations tend to be lower for drench applications (Currey and Lopez, 2010). Considering the slow uptake of ethephon as a spray application and the resulting logistical issues with plant irrigation and handling, ethephon drenches could have a practical application in the commercial greenhouse industry should they prove effective.

The objective of this study was 2-fold: 1 ) to determine if ornamental perennial plant 
species could respond to ethephon substrate drenches and the subsequent effect on growth and development of the shoots; and 2) to determine how differences in substrate $\mathrm{pH}$ affect ethephon efficacy by analyzing the shoot responses to the substrate drench application over a range of starting substrate $\mathrm{pH}$.

\section{Materials and Methods}

Two perennial plant species were studied. Verbena bonariensis L. 'Lollipop' (purpletopvervain) and Veronica spicata L. 'Goodness Grows' (spiked speedwell), based on their response to foliar applications of ethephon in previous studies (Grossman et al., 2011). Plants were propagated from unrooted cuttings, which received a 10 -second basal dip of $1500 \mathrm{mg} \cdot \mathrm{L}^{-1}$ indole-3-butyric acid (IBA) rooting hormone (Hortus IBA Water Soluble Salts 20\% IBA; Hortus USA Corp., New York, NY). Cuttings were rooted in 72 cell trays (cell height $5.7 \mathrm{~cm}$, volume $35.4 \mathrm{~mL}$ ) in a soilless substrate (Fafard 1P, Sun Gro Horticulture, Agawam, MA) consisting of $80 \%$ Canadian sphagnum peatmoss, combined with perlite, dolomitic limestone, and a wetting agent. Cuttings were rooted under a clear water mist and bottom heat at $22{ }^{\circ} \mathrm{C}$. After root initials had formed ( 9 to $14 \mathrm{~d}$, depending on the species), liners were removed from mist and bottom heat and irrigated with constant liquid feed (CLF) using $150 \mathrm{mg} \cdot \mathrm{L}^{-1}$ nitrogen $15 \mathrm{~N}-2.2 \mathrm{P}-12.5 \mathrm{~K} 4 \mathrm{Ca}-$ $2 \mathrm{Mg}$ (Jack's Professional LX Peat-Lite fertilizer, J.R. Peters Inc., Allentown, PA). Liners were allowed to grow to a wellrooted, transplantable size ( 3 and 6 weeks for Verbena and Veronica, respectively).

To satisfy the vernalization requirement of the Veronica, after 6 weeks of growth, Veronica liners were vernalized at $5{ }^{\circ} \mathrm{C}$ with $3.7 \mu \mathrm{mol} \cdot \mathrm{m}^{-2} \cdot \mathrm{s}^{-1}$ of light supplied by lightemitting diodes (LEDs) for $9 \mathrm{~h} / \mathrm{d}$ in a walk-in cooler for 6 weeks. After vernalization, liners were allowed $5 \mathrm{~d}$ to resume active growth before transplanting.

Liners were transplanted into trade gallon pots (volume $2.8 \mathrm{~L}$ ) in a blended substrate consisting of $85 \%$ Canadian sphagnum peatmoss (Sun Gro Horticulture), 15\% coarse perlite (PVP Industries, North Bloomfield, $\mathrm{OH})$ with the addition of $0.59 \mathrm{~kg} \cdot \mathrm{m}^{-3}$ of gypsum and $0.59 \mathrm{~kg} \cdot \mathrm{m}^{-3}$ of Micromax granular micronutrients (Everris NA Inc., Dublin, $\mathrm{OH})$. We conducted preliminary studies to determine the volume of dolomitic lime needed in the substrate to achieve our target $\mathrm{pH}$ values. Substrate $\mathrm{pH}$ was adjusted by adding 1.19 to $7.11 \mathrm{~kg} \cdot \mathrm{m}^{-3}$ dolomitic lime to achieve target $\mathrm{pH}$ values of $4.5,5.0,5.5$, $6.0,6.5$, and 7.0 (Table 1). A wetting agent (Aqua Gro 2000L, Aquatrols®, Paulsboro, NJ) was incorporated in the substrate at a rate of $68 \mathrm{~mL} \cdot \mathrm{m}^{-3}$ and the substrate was allowed to equilibrate for 1 week before transplanting at which time the $\mathrm{pH}$ was sampled for starting $\mathrm{pH}$ values using the Saturated Media Extract (SME) method.

Ethephon (Collate; Fine Americas, Inc., Walnut Creek, CA) was applied as a substrate

Table 1. Target and actual substrate $\mathrm{pH}$ of Verbena bonariensis 'Lollipop' and Veronica spicata 'Goodness Grows' grown in a custom blended substrate of peat and perlite amended with dolomitic lime, gypsum and micronutrients. Substrate $\mathrm{pH}$ monitored by Saturated Media Extract method at 0, 2 , 10 , or $28 \mathrm{~d}$ after potting plants.

\begin{tabular}{lccccc}
\hline Target $\mathrm{pH}$ & Lime added $\left(\mathrm{kg} \cdot \mathrm{m}^{-3}\right)$ & $\mathrm{pH}$ Day 0 & $\mathrm{pH}$ Day 2 & $\mathrm{pH}$ Day 10 & $\mathrm{pH}$ Day 28 \\
\hline Verbena & 1.19 & $4.6^{\mathrm{z}}$ & 4.5 & 4.3 & 4.3 \\
4.5 & 1.63 & 5.0 & 5.0 & 4.9 & 4.9 \\
5.0 & 2.22 & 5.3 & 5.4 & 5.4 & 5.3 \\
5.5 & 2.84 & 5.9 & 6.0 & 5.8 & 5.7 \\
6.0 & 4.15 & 6.5 & 6.5 & 6.4 & 6.3 \\
6.5 & 7.11 & 6.8 & 6.8 & 6.7 & 6.7 \\
7.0 & & & & 4.5 & 4.4 \\
Veronica & 1.19 & $4.3^{z}$ & 4.3 & 4.8 & 4.8 \\
4.5 & 1.63 & 4.9 & 4.5 & 5.3 & 5.4 \\
5.0 & 2.22 & 5.3 & 5.2 & 5.7 & 5.9 \\
5.5 & 2.84 & 5.8 & 5.7 & 6.2 & 6.3 \\
6.0 & 4.15 & 6.3 & 6.2 & 6.6 & 6.7 \\
6.5 & 7.11 & 6.7 & 6.6 & & \\
7.0 & & & & & \\
\hline
\end{tabular}

${ }^{\mathrm{z}}$ Means of three replicates.

drench 1 week after transplant. Care was taken to ensure that solution applied did not make contact with any foliar tissue. The ethephon drench was applied to moderately moist substrate during cloudy weather conditions. The temperature at the time of chemical application to the Veronica was $22.5{ }^{\circ} \mathrm{C}$ and the relative humidity was $46 \%$. The temperature at the time of the ethephon application to Verbena was $18.9^{\circ} \mathrm{C}$ with $40 \%$ relative humidity. Ethephon was applied at $100 \mathrm{mg} \cdot \mathrm{L}^{-1}$ at a volume of $296 \mathrm{~mL}$ per pot to eight single-plant replicates in each of the six substrate $\mathrm{pH}$ groups. The ethephon solution combined with municipal tap water (alkalinity $55 \mathrm{mg} \cdot \mathrm{L}^{-1} \mathrm{CaCO}_{3}$ ) measured $4.2 \mathrm{pH}$ (HI9811 pH meter; Hannah Instruments, Ann Arbor, MI) at the time of application for both crops; therefore no additional acidifiers were used. Untreated plants (eight replicates) in each of the six substrate $\mathrm{pH}$ levels were drenched with water which had been acidified to a $\mathrm{pH}$ of 4.2 using Indicate Phase 5 buffer solution (Brandt Consolidate, Inc., Springfield, IL) to serve as the control groups. Plants were grown in a double polyethylene greenhouse located in Blacksburg, VA (lat. $37.23^{\circ} \mathrm{N}$, long. $80.42^{\circ} \mathrm{W}$ ). The $\mathrm{Ve}$ ronica crop was grown from 13 Mar. 2014 to 12 May 2014, and temperatures averaged $22.2^{\circ} \mathrm{C} / 19.1^{\circ} \mathrm{C}$ day/night. The Verbena crop was grown 1 Apr. 2014 to 20 May 2014 and the day/night temperatures averaged $21.8^{\circ} \mathrm{C} /$ $17.7^{\circ} \mathrm{C}$. Plants were grown under a minimum of $14 \mathrm{~h}$ long days using supplemental $600 \mathrm{~W}$ high pressure sodium (HPS) lighting for day length extension until 10 May 2014, at which point the natural day length exceeded $14 \mathrm{~h}$. The daily light integral (DLI) in the greenhouse averaged $19.6 \mathrm{~mol} \cdot \mathrm{m}^{-2} \cdot \mathrm{d}^{-1}$ during the growth of the Veronica and $18.8 \mathrm{~mol} \cdot \mathrm{m}^{-2} \cdot \mathrm{d}^{-1}$ for the Verbena. Each plant species was set up as a separate experiment in a completely randomized design.

Data were collected at 0,2 , and 4 weeks after the drench application and at termination of the study (determined by plant flowering). Data collected included plant height, average plant width (average of width measured at the widest point of the plant and then the perpendicular width) and days to flower.
Shoots were harvested on the termination of the study and dried at $65{ }^{\circ} \mathrm{C}$ for 1 week to measure dry weight. The $\mathrm{pH}$ of each substrate $\mathrm{pH}$ level was measured using the SME method at $0,2,10$, or $28 \mathrm{~d}$ after potting for Verbena and Veronica (Table 1). Substrate samples for $\mathrm{pH}$ analysis were taken from the middle one third of the pot. This method was a destructive harvest and additional plants were built into the study to accommodate these samples.

To determine the significance of the ethephon efficacy within a single substrate $\mathrm{pH}$, data were analyzed by ANOVA $(P \leq$ 0.05 , Student's $t$ test) using JMP ${ }^{\circledR} 9.0 \bigodot 2010$ (SAS Institute Inc., Cary, NC). To determine the substrate $\mathrm{pH}$ response, data were analyzed via regression analyses over substrate $\mathrm{pH}$. To determine the interaction of the ethephon drench and substrate $\mathrm{pH}$, linear fit regressions were further analyzed using a multivariate linear regression model including an interaction term (cross term) in JMP $\AA 9.0 @$ 2010. Quadratic regression models were further analyzed in R (R Development Core Team, 2010) using a model comparison via an F test for Verbena shoot dry weight. A quadratic regression was necessary as both the untreated plants and the ethephon-treated plants showed a quadratic response, but only the ethephon-treated plants demonstrated a linear response.

\section{Results}

Actual substrate $\mathrm{pH}$ at the time of the 100 $\mathrm{mg} \cdot \mathrm{L}^{-1}$ ethephon drench was within \pm 0.3 units of the target $\mathrm{pH}$ (Table 1). The $\mathrm{pH}$ of the substrates remained relatively stable throughout the study for Verbena and Veronica with a standard error of 0.03 .

Verbena bonariensis 'Lollipop'. At 6 weeks after drench application, Verbena plants showed a significant response to ethephon at all substrate $\mathrm{pH}$ levels when compared with controls (Figs. 1 and 2). Plant height was significantly reduced by ethephon at substrate $\mathrm{pH}$ levels 4.5, 5.0, 5.5, 6.0, or 6.5; however, there was no significant reduction of height at substrate $\mathrm{pH} 7.0$ as compared with plants in the control groups (Fig. 1A). 
The ethephon drench significantly reduced average plant width (Fig. 1B) and shoot dry weight (Fig. 2A) across all substrate $\mathrm{pH}$ levels compared with untreated plants grown under the same substrate $\mathrm{pH}$ levels. In addition, the ethephon drench resulted in a significant flower delay in all treated plants, regardless of substrate $\mathrm{pH}$ compared with control plants (Fig. 2B).

Furthermore, for Verbena, there were significant differences in the multivariate linear regression model comparison of the ethephondrenched plants to the controls (Figs. 1 and 2). The differing slopes of the lines representing the ethephon-drenched group and the control group shows the interaction of substrate $\mathrm{pH}$ and the ethephon drench. Within the ethephondrenched plants, plant height (Fig. 1A) and width (Fig. 1A) increased significantly with increasing substrate $\mathrm{pH}$ while the control plant measurements in these same parameters remained relatively static regardless of changing substrate $\mathrm{pH}$. Substrate $\mathrm{pH}$ affected shoot dry weight of both control and ethephondrenched plants, however the effect of increasing substrate $\mathrm{pH}$ on shoot dry weight was different depending on whether ethephon was applied (Fig. 2A). Shoot dry weight increased with increasing substrate $\mathrm{pH}$ in plants in the ethephon-drenched group, while plants in the control group exhibited a quadratic response with an increase in shoot dry weight at substrate $\mathrm{pH}$ levels 4.5 to 5.5 , but declining shoot dry weight as substrate $\mathrm{pH}$ continued to rise. The number of days to flower decreased with increasing substrate $\mathrm{pH}$ for ethephon-drenched plants, while flowering time of control plants was unaffected by substrate $\mathrm{pH}$ (Fig. 2A).

Veronica spicata 'Goodness Grows'. There were no significant differences in the parameters measured across substrate $\mathrm{pH}$ levels and therefore data were pooled. Across all substrate pHs, Veronica showed a significant response to the ethephon drench when compared with the control group (Table 2). Plant height of ethephon-drenched plants was less than that of control plants at 4 weeks after application, though finished (8 weeks after application) plant height showed no significant difference. Average width and shoot dry weight of the ethephon-drenched plants were significantly reduced in finished plants as compared with the control plants. However, the number of days to plant flowering was unaffected by the ethephon drench.

When examining the effect of substrate $\mathrm{pH}$ on growth of the ethylene-drenched plants in comparison with the controls, the regression analysis of the two models showed no significant difference between the slopes of the ethephon drench line compared with the control line at 2,4 , or 8 weeks after application (data not presented), indicating that substrate $\mathrm{pH}$ did not significantly influence the efficacy of the ethephon drench application.

\section{Discussion}

Ethephon response. Both species studied responded to the ethephon substrate drench application. Verbena plants subjected to
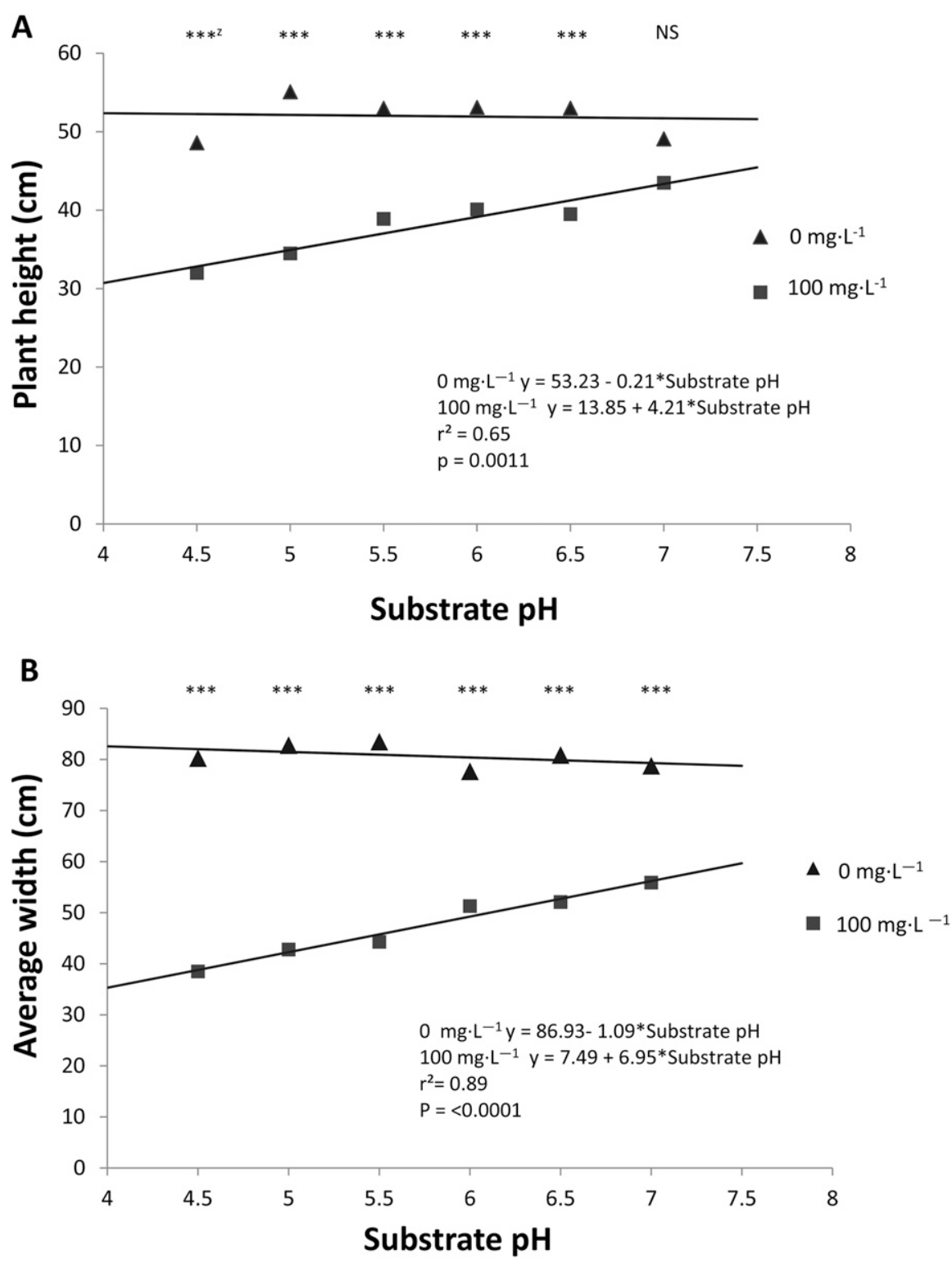

Fig. 1. The correlation between the growth response of Verbena bonariensis 'Lollipop' to the $100 \mathrm{mg} \cdot \mathrm{L}^{-1}$ ethephon drench applied 1 week after potting and increasing substrate $\mathrm{pH}$ at 6 weeks after the drench application along with the regression equations and coefficient of determination $\left(r^{2}\right)$ for the growth parameters of total plant height in centimeters $(\mathbf{A})$ and average plant width in centimeters $(\mathbf{B})$. Changes in slope indicate the linear effect of increasing substrate $\mathrm{pH}$. Points are means of eight replicates. Slope equations within the table are for the individual regressions. Significance of individual regression equations:

\begin{tabular}{lllllll}
\hline Height & $0 \mathrm{ppm}$ & $\mathrm{L}^{\mathrm{NS}}$ & $r^{2}=0.001$ & $100 \mathrm{mg} \cdot \mathrm{L}^{-1}$ & $\mathrm{~L}^{* * * *}$ & $r^{2}=0.3248$ \\
Width & $0 \mathrm{ppm}$ & $\mathrm{L}^{\mathrm{NS}}$ & $r^{2}=0.43$ & $100 \mathrm{mg} \cdot \mathrm{L}^{-1}$ & $\mathrm{~L}^{* * *}$ & $r^{2}=0.2330$ \\
\hline
\end{tabular}

${ }_{\mathrm{NS}}, *, * *, * * *$, and $* * * *$ Nonsignificant, significant at $0.05,0.01,0.001$, and 0.0001 , respectively.

ethephon drenches exhibited reduced height and average width persisting through 6 weeks after application, a reduction in finished shoot dry weight and a significant delay in flowering. The significant flower delay in treated plants could be problematic in production when applying ethephon to plant material after transplant. However, all plants had flowered within 6 weeks from the time of the ethephon drench, which is within the predicted crop production schedule of 6 to 8 weeks (Green Leaf Plants ${ }^{\circledR}$, 2014). In addition, the delay in flowering could prove advantageous when ethephon is used in liner production on crops that are prone to early flowering during propagation.
Veronica's response to the ethephon drench was less pronounced, there was an initial height reduction, but it did not persist in the finished plants. Average width and shoot dry weight were reduced at finish on ethephondrenched plants. Ethephon caused no significant flower delay in this crop. So, it is possible a higher rate or multiple applications of ethephon could increase growth control without adversely affecting flowering.

$p H$ and ethephon interaction. There was a substrate $\mathrm{pH}$ response within the Verbena plants drenched with ethephon. As the substrate $\mathrm{pH}$ increased, there was less effect on plant growth, for example, values in the 


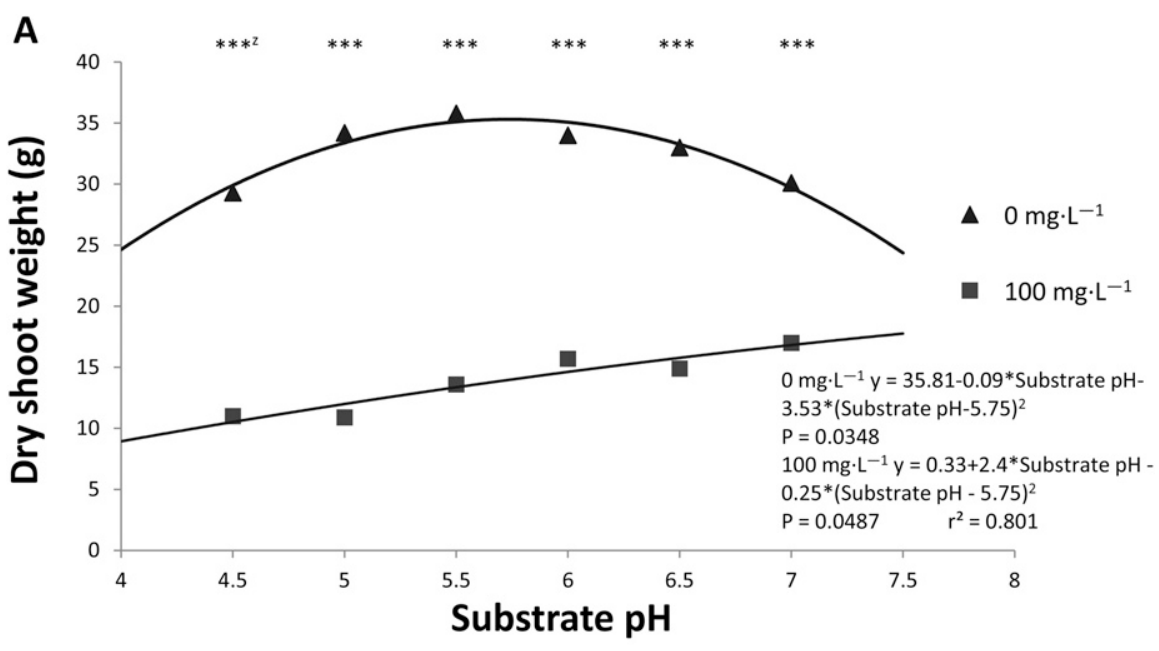

B

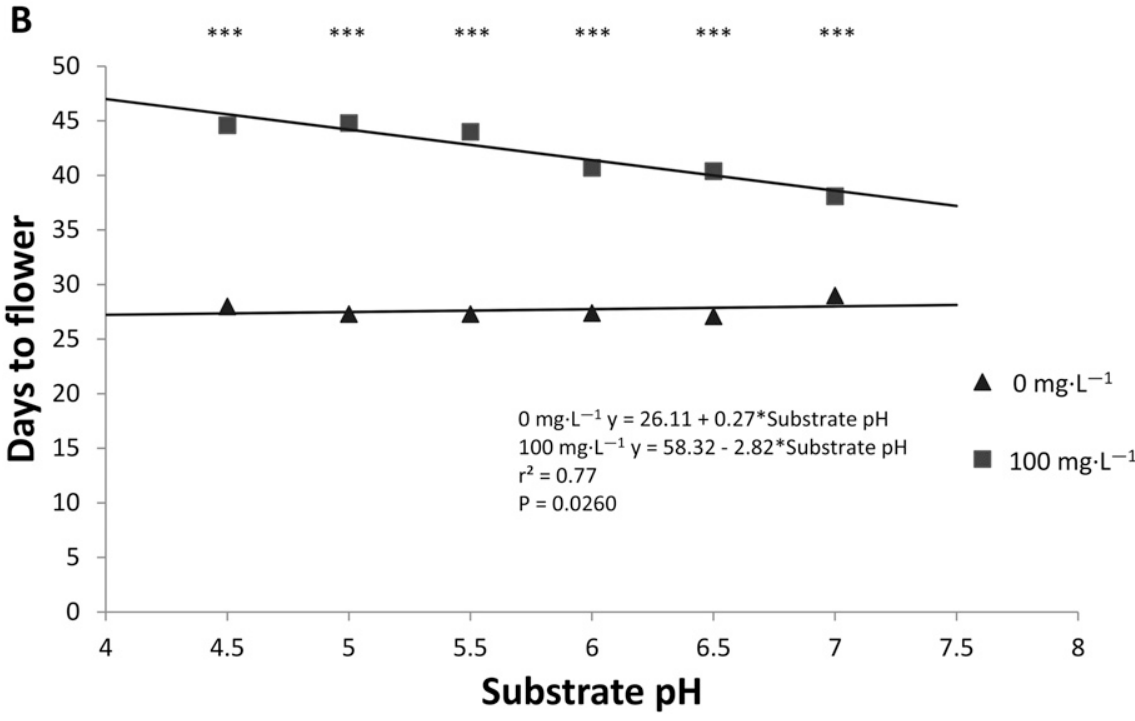

Fig. 2. The correlation between the growth response of Verbena bonariensis 'Lollipop' to the 100 $\mathrm{mg} \cdot \mathrm{L}^{-1}$ ethephon drench applied 1 week after potting and increasing substrate $\mathrm{pH}$ at 6 weeks after the drench application along with the regression equations and coefficient of determination $\left(r^{2}\right)$ for the growth parameters of (A) final shoot dry weight in grams fit quadratically. $\mathrm{pH}$ significantly influenced shoot dry weight of both the control group and the ethephon drenched group. Days to flower from transplant (B) was fit as a linear regression. Changes in slope indicate the linear effect of increasing substrate $\mathrm{pH}$. Points are means of eight replicates. Slope equations within the table are for the individual regressions. Significance of individual regression equations:

\begin{tabular}{lllllll}
\hline Shoot dry weight & $0 \mathrm{mg} \cdot \mathrm{L}^{-1}$ & $\mathrm{Q}^{*}$ & $r^{2}=0.15$ & $100 \mathrm{mg} \cdot \mathrm{L}^{-1}$ & $\mathrm{Q}^{* *}$ & $r^{2}=0.23$ \\
Days to flower & $0 \mathrm{mg} \cdot \mathrm{L}^{-1}$ & $\mathrm{~L}^{\mathrm{NS}}$ & $r^{2}=0.003$ & $100 \mathrm{mg} \cdot \mathrm{L}^{-1}$ & $\mathrm{~L}^{* * *}$ & $r^{2}=0.26$
\end{tabular}

${ }_{\mathrm{NS}}, *, * *, * * *$, and $* * * *$ Nonsignificant, significant at $0.05,0.01,0.001$, and 0.0001 , respectively.

Table 2. Plant height, average width, final shoot dry weight $(\mathrm{g})$ and days to flower of Veronica spicata 'Goodness Grows' at 4 and 8 weeks after ethephon applications under substrate $\mathrm{pH}$ of 4.5, 5.0, 5.5, 6.0, 6.5 , or 7.0 (data pooled due to nonsignificance among substrate $\mathrm{pH}$ levels).

\begin{tabular}{lcccccccc}
\hline & \multicolumn{2}{c}{ Plant ht $(\mathrm{cm})$} & & \multicolumn{2}{c}{ Plant width $(\mathrm{cm})$} & & Shoot wt $(\mathrm{g})$ & \multicolumn{2}{c}{ Days to flower } \\
\cline { 2 - 3 } Plant growth regulator $(\mathrm{PGR})$ & $4 \mathrm{wk}$ & $8 \mathrm{wk}$ & & $4 \mathrm{wk}$ & $8 \mathrm{wk}$ & & $8 \mathrm{wk}$ & $8 \mathrm{wk}$ \\
\hline Untreated control 0 $\mathrm{mg} \cdot \mathrm{L}^{-1}$ & 18.8 & 34.0 & & 19.0 & 34.9 & & 18.4 & 43.0 \\
Ethephon drench 100 $\mathrm{mg} \cdot \mathrm{L}^{-1}$ & 16.2 & 33.8 & & 17.8 & 31.6 & & 13.6 & 43.5 \\
PGR effect & $* \mathrm{y}$ & $\mathrm{NS}$ & & $*$ & $* * * *$ & & $* * * *$ & NS \\
\hline
\end{tabular}

${ }^{\mathrm{z}}$ Days to flower calculated from the day of transplant.

$\mathrm{y}_{\mathrm{NS}}, * * *, * * *$, and $* * * *$ Nonsignificant, significant at $0.05,0.01,0.001$, and 0.0001 , respectively.

measured parameters of height, width, and shoot weight all increased significantly with increasing substrate $\mathrm{pH}$. Flowering delay was also less pronounced at higher $\mathrm{pH}$ levels. This demonstrates that the additional buffering capacity of the dolomitic lime directly influenced the efficacy of the ethephon drench. As less effect on final solution $\mathrm{pH}$. This same principle can be applied to substrate drenches. Although the $\mathrm{pH}$ of the solution applied was consistent at $\mathrm{pH} 4.2$, that solution was altered when applied as a substrate drench, subsequently combining with the pore water within the substrate. The new combined solution's buffering capacity was influenced by the level of bicarbonates in the substrate. For our studies, within the normal growing range (pH 5.5 to 6.5), changes in the level of growth reduction were all within an acceptable range. However, under lower $\mathrm{pH}$ levels, the buffering capacity is also greatly reduced, allowing for the potential for significant increases in ethephon efficacy. At higher $\mathrm{pH}$ levels, the buffering capacity could be high enough to limit ethephon efficacy. The significant shoot growth reduction response to ethephon applied through a substrate drench application seems to support the research by Edgerton and Hatch (1972), that ethephon could be taken up through the plant roots and translocated to the shoots where conversion to ethylene occurs intercellularly (Warner and Leopold, 1969).

In addition, it appears that because a stronger growth reduction occurred at lower $\mathrm{pH}$ levels, the rate of ethephon degradation in the substrate increased with increasing substrate $\mathrm{pH}$, resulting in rapid dissipation of the ethylene and less subsequent uptake of ethephon at higher substrate $\mathrm{pH}$. This theory is consistent with the description of Miller et al. (2012) of greater and faster ethylene evolution from a peatmoss substrate adjusted (with lime) to $\mathrm{pH}$ greater than 5.1 in a closed, nonplant system. Alternatively, the lower substrate $\mathrm{pH}$ resulted in less ethephon degradation and consequently some persistence in the substrate, resulting in a prolonged uptake of ethephon by the plants. This is again consistent with the Miller et al. (2012) hypothesis that because the evolution of ethylene occurs over a longer span of time at lower substrate $\mathrm{pH}$, there is somewhat of a slow release effect, where the plant not only takes up the ethephon at the time of application, but continuously over days or even weeks.

The variability in growth responses between the two plant species studies shows that ethephon drench responses seem to be species and possibly cultivar specific, just as in spray applications. The species specific response is further supported in work by Miller et al. (2012), in which ethephon drenches were applied to multiple bedding plant crops, which responded in varying degrees. Whipker (2015) also found varying responses to ethephon in regards to branching between cultivars of petunias. Petunia $\times$ hybrida 'Supertunia Vista Bubblegum' responded to the ethephon drench with a significant increase in branching, while 'Supertunia Double Peppermint' showed no significant change in branching.

Although we did not measure the plants' root response to the ethephon drench application, it is worth noting that Miller et al. (2012) reported a reduction in the root dry weight of finished bedding plants treated with ethephon drenches. This is important to note, 
as reduced root mass has the potential to influence shoot growth. We observed a reduction in root dry weight on Veronica 'Goodness Grows' in a previous study (Latimer, 2014); wherein root dry weight was reduced $23 \%$ with an ethephon liner drench of $500 \mathrm{mg} \cdot \mathrm{L}^{-1}$ when compared with the controls (unpublished data). We expected the much lower rate of $100 \mathrm{mg} \cdot \mathrm{L}^{-1}$ used in this study to result in minimal reductions in root mass on the Veronica, as the data of Miller et al. (2012) show less effect on root dry weight as ethephon drench rates are reduced. Even in finished Verbena plants subjected to the ethephon drench where shoot dry weights were reduced up to $66 \%$, there were no visual differences in the extent of rooting in the container compared with the controls (personal observation).

Our results support ethephon drenches as a promising method of application of the chemical. However, it is currently not EPA labeled for drench applications. Although drench applications of ethephon could help growers overcome the challenge of reduced uptake and efficacy because of reduced leaf wetness duration following spray applications, it does present another challenge in managing $\mathrm{pH}$ effectively for not only plant growth, but also to ensure the efficacy of the ethephon drenches. Our research indicates that the influence of substrate $\mathrm{pH}$ on the ethephon response can vary dependent on the species. For the two species tested, Veronica longifolia 'Goodness Grows' and Verbena bonariensis 'Lollipop', Veronica growth was not influenced by substrate $\mathrm{pH}$ in either the control or ethephondrenched plants, but there was a significant interaction of substrate $\mathrm{pH}$ and the efficacy of the ethephon drench in the Verbena crop. Within the recommended substrate $\mathrm{pH}$ growing range for greenhouse grown crops $(\mathrm{pH} 5.8$ to 6.4) (Fisher, 2003), ethephon uptake resulted in satisfactory growth control in our studies. However, because the efficacy of the ethephon drench was directly influenced by substrate $\mathrm{pH}$ in Verbena, there is the potential for overregulation on some crops under low substrate $\mathrm{pH}$ conditions, and conversely high substrate $\mathrm{pH}$ conditions could reduce ethephon efficacy.

\section{Literature Cited}

Burg, S.P. 1973. Ethylene in plant growth. Proc. Natl. Acad. Sci. USA 70:591-597.

Camberato, D.M., J. Camberato, and R. Lopez. 2014. Determining the effect of carrier water $\mathrm{pH}$ and bicarbonate concentration on final $\mathrm{pH}$ of plant growth regulator solutions. HortScience 49:1176-1182.

Currey, C.J. and R.G. Lopez. 2010. Applying plant growth retardants for height control. Purdue Ext. HO-248-W. 9 Dec. 2014. <https://www. extension.purdue.edu/extmedia/HO/HO-248W.pdf $>$.

Edgerton, L.J. and A.H. Hatch. 1972. Absorption and metabolism of ${ }^{14} \mathrm{C}$ (2-chloroethyl) phosphonic acid in apples and cherries. J. Amer. Soc. Hort. Sci. 97:112-115.

Fisher, P. 2003. Managing $\mathrm{pH}$ for container media, p. 39-45. In: D. Hamrick (ed.). Ball Redbook crop production Vol. 2. Ball Publishing, Batavia, IL.

Green Leaf Plants $\AA$, A Division of Aris Horticulture, Inc. 2014. Technical Guide.Verbena bonariensis 'Lollipop'. 20 Nov. 2014. <http:// www.glplants.com/plants/3792-Verbenabonariensis-Lollipop>.

Grossman, M., J. Freeborn, H. Scoggins, and J. Latimer. 2011. Branching agents improve quality of herbaceous perennial liners. OFA Bulletin No. 930. p. 4-7. Nov./Dec. 2011.

Haver, D.L. and U.K. Schuch. 2001. Influence of root restriction and ethylene exposure on apical dominance of petunia. Plant Growth Regulat. 35:187-196.

Johnson, C.R., D.B. McConnell, and J.N. Joiner. 1982. Influence of ethephon and light intensity on growth and acclimatization of Ficusbenjamina. HortScience 17:614-615.

Kays, S.J. and R.M. Beaudry. 1987. Techniques for inducing ethylene effects. Acta Hort. 201:77106.
Latimer, J.G. 2014. More ethephon options with Collate on herbaceous perennial liners. E-Gro Alert 3(4):1-2.

Lougheed, E.C. and E.W. Franklin. 1972. Effects of temperature on ethylene evolution from ethephon. Can. J. Plant Sci. 52:769-773.

Miller, W.B., N. Mattson, X. Xie, D. Xu, C. Currey, K. Clemens, R. Lopez, M. Olrich, and E. Runkle. 2012. Ethephon substrate drenches inhibit stem extension of floriculture crops. HortScience 47:1312-1319.

Mudge, K.W. and B.T. Swanson. 1978. Effect of ethephon, indole butyric acid, and treatment solution $\mathrm{pH}$ on rooting and on ethylene levels within mung bean cuttings. Plant Physiol. 61:271-273.

Olien, W.C. and M.J. Bukovac. 1978. The effect of temperature on rate of ethylene evolution from ethephon and from ethephon-treated leaves of sour cherry. J. Amer. Soc. Hort. Sci. 103:199202.

R Development Core Team. 2010. R: A language and environment for computing. $\mathrm{R}$ Foundation for Statistical Computing, Vienna, Austria. $<$ http://www.R-project.org $>$.

Smith, T. 2010. Effects of $\mathrm{pH}$ on pesticides and growth regulators. UMass Ext. 3 Oct. 2013. $<\mathrm{http}$ ://extension.umass.edu/floriculture/ fact-sheets/effects-ph-pesticides-and-growthregulators $>$

Styer, R.C. 2002. Using florel effectively. Greenhouse Product News 12(10):10-15.

Warner, H.L. and A.C. Leopold. 1969. Ethylene evolution from 2-chloroethylphosphonic acid. Plant Physiol. 44:156-158.

Whipker, B.E., J. Gibson, T. Cavins, I. McCall, and P. Konjoian. 2003. Growth regulators, p. 85-92. In: D. Hamrick (ed.). Ball Redbook crop production Vol. 2. Ball Publishing, Batavia, IL.

Whipker, B.E. 2015. Branching out with Collate. Plant growth regulators for annuals. Grower Talks insert January 2015, 48 pp.

Yates, R., J. Lutz, and V. Burbaker. 2011. Optimum pesticide spray water $\mathrm{pH}$ using Indicate 5. Griffin Greenhouse and Nursery Supplies, Inc. 14 Nov. 2014. <http:// www.ggspro.com/new/pdfs/Opt-Pest-Spray. pdf>. 